\title{
Distribution and abundance of Neocrangon resima (Rathbun, 1902) (Decapoda: Caridea: Crangonidae) collected during the TALUD XIV cruise in the Gulf of California, Mexico
}

\author{
Michel E. Hendrickx
}

Laboratorio de Invertebrados Bentónicos, Unidad Académica Mazatlán, Instituto de Ciencias del Mar y Limnología, Universidad Nacional Autónoma de México, P.O. Box 811, Mazatlán, Sinaloa 82000, Mexico. E-mail: michel@ola.icmyl.unam.mx

\section{Abstract}

A large population of Neocrangon resima (Rathbun, 1902) is reported for the northern Gulf of California, Mexico, in depths of 205-580 m, with environmental conditions varying from 6.21 to $11.29^{\circ} \mathrm{C}$ and 0.50 to $1.54 \mathrm{ml} \mathrm{O}_{2} / 1$. With a total of 33 specimens collected, this is the largest sample reported to date for the northern Gulf of California. The species had previously been reported from two localities. The distribution range in this area is increased by ca $1^{\circ} 30^{\prime}$ of latitude to the south. Maximum and minimum estimated densities were of 2.7 and 54.0 orgs/ha, thus indicating that a relatively large population of $N$. resima occurs in the area.

Key words: Crangonidae, distribution, Gulf of California, Mexico.

\section{Introduction}

Crangonid shrimps are distributed worldwide in both shallow and deep waters (Chace, 1984; Wicksten, 1989; Hendrickx, 1995, 2012). Several species are of commercial importance and shallow-water species are mostly found in temperate waters (Holthuis, 1980). According to Holthuis (1993) and Komai (2004), the Crangonidae is comprised of 21 genera and to date 212 species (De Grave \& Fransen, 2011). In total, 56 species of Crangonidae have been reported for the American coasts, 37 in the eastern Pacific (Hendrickx, 2012). Many shallow water species of crangonids originally were described in the genus Crangon Fabricius, 1798, and later transferred to new genera (e.g. Lissocrangon Curis \& Carlton, 1977; Mesocrangon
Zarenkov, 1965; Metacrangon Zarenkov, 1965; Neocrangon Zarenkov, 1965) when species of this group were studied more thoroughly.

Seven species of deep-water $(>200 \mathrm{~m}$ depth) crangonids have so far been reported in the Mexican Pacific (Hendrickx, 2012), six of them from shallow waters. Of these, five are known exclusively from the California Current area: Crangon handi (Kuris \& Carlton, 1977), Crangon holmesi Rathbun, 1902, Crangon nigromaculata Lockington, 1877, Mesocrangon spinosissimus (Rathbun, 1907), and Neocrangon resima (Rathbun, 1902). The sixth species, Mesocrangon munitella (Walker, 1898), has been reported in both the California Current area and in the Gulf of California (Hendrickx, 1993). Neocrangon zacae (Chace, 1937), reported by Hendrickx (1993) for the California Current area and the Gulf of California, is a junior synonym of Neocrangon 
resima (Wicksten, 1996). So far, there has been no reports of shallow water Crangonidae in SW Mexico (i.e., south of Banderas Bay).

The TALUD project, initiated in 1989 with very extensive sampling programs in 2000-2001 and from 2005 to 2011, is aimed at studying the biocenosis of habitats below the $200 \mathrm{~m}$ depth limit along the Pacific coast of Mexico. However, due to the presence of a very wide minimum oxygen zone (OMZ) in the area, particularly in the southern and central Gulf of California and off SW Mexico, severe hypoxia and anoxia exist, and sampling activities were performed in deeper water, below the $700 \mathrm{~m}$ depth limit, where the oxygen concentration progressively increases allowing for the presence of a distinct, speciesrich invertebrate and fish community (see Hendrickx and Serrano, 2010; Serrano and Hendrickx, 2011). This study reports on the presence of a widely distributed population of Neocrangon resima (Rathbun, 1902) in the northern Gulf of California.

\section{Materials and Methods}

The material was obtained while sampling with the R/V "El Puma" of the Universidad Nacional Autónoma de México in the northern part of the Gulf of California, roughly between $28^{\circ} 10^{\prime}$ and $29^{\circ} 10^{\prime} \mathrm{N}$. A total of 30 stations were visited between the $5^{\text {th }}$ and the $11^{\text {th }}$ of April, 2011, with depth ranging from 148 to $1346 \mathrm{~m}$. Specimens were collected in a $2.35 \mathrm{~m}$ wide by $0.95 \mathrm{~m}$ high standard benthic sledge operated during 30 minutes at an average hauling speed of 1.75 knots, and equipped with an outer collecting net of ca 5.5 $\mathrm{cm}(21 / 4$ ") stretch mesh and an inner net of ca $2.0 \mathrm{~cm}(3 / 4 ")$ stretch mesh. Density was estimated using the swept area method (width $\mathrm{x}$ trawling distance of the gear). Sampling depth was estimated with a digital SIMRAD echo sounder. Epibenthic temperature and oxygen concentrations were measured ca 10 $\mathrm{m}$ above bottom level with a Seabird CTD-O, probe. Oxygen level were also double-checked with the Winkler method using water samples collected in closing bottles near bottom.

The specimens examined are deposited in the invertebrate collection at the Mazatlán Marine Station, UNAM, in Mazatlán, Mexico (EMU), with their respective catalogue number. Abbreviations used are: CL, carapace length (posterior margin of orbit to midpoint of posterodorsal margin of carapace); St., sampling stations. A restricted synonymy is provided, including mostly contributions where the species is illustrated.

\section{Results}

Neocrangon resima (Rathbun, 1902)

Fig. 1

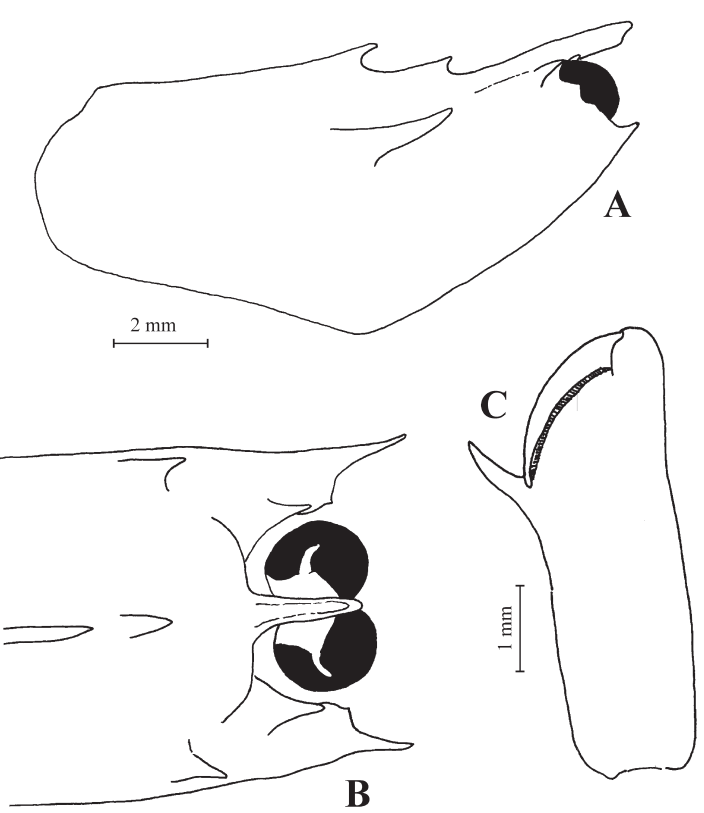

Figure 1. Neocrangon resima (Rathbun, 1902). A. Carapace, lateral view. B. Anterior part of carapace, dorsal view. C. Chela of left first pereiopod, lateral view. Setae omitted.

Crangon resima Rathbun, 1902: 889; 1904: 124, fig. 65. - Kozloff, 1974: 164 (key).-Word and Charwat, 1976: 68 (key), 87 (text-fig.), 88.- Butler 1980: 97 (key).- Luke, 1977: 18 (catalogue).

Crago resima.- Schmitt, 1921: 96, fig. 64.Goodwin, 1952: 394.

Crago zacae Chace, 1937: 136, text-fig. 9.

Crangon (Neocrangon) resima.- Zarenkov 1965: 1762.

Crangon (Neocrangon) zacae.- Zarenkov 1965: 1764. 
Crangon zacae.- Word and Charwat, 1976: 93 (text-fig.), 94.- SIO, 1992: 100 (catalogue).

Neocrangon zacae.- Kuris and Carlton, 1977: 554.- Wicksten, 1980: 39.- Austin, 1985: 637 (list).- Hendrickx, 1993: 306 (list).

Neocrangon resima.- Kuris and Carlton, 1977: 554.- Austin, 1985: 637 (list).- Wicksten, 1996: 42, fig. 1 a-c; 2011: 159.- Wicksten and Hendrickx, 2003: 69 (list).- De Grave and Fransen, 2011: 999 (list).

Material examined: TALUD XIV (Figs. 2,3). St. 8 (28 $\left.17^{\prime} 06^{\prime \prime} N-112^{\circ} 33^{\prime} 39^{\prime \prime} \mathrm{W}\right), 8 /$ April/2011, one female (CL $7.9 \mathrm{~mm}$ ), 520$557 \mathrm{~m}$, Agassiz dredge (EMU-9453). St. 10 (28 $20^{\prime} 50^{\prime \prime} \mathrm{N}-112^{\circ} 11^{\prime} 40$ ” W), six females (CL 6.9-9.0 mm), 8/April/2011, Agassiz dredge, 325-328 m (EMU-9454). St. 14 (28³6'14”N, $\left.112^{\circ} 28^{\prime} 03^{\prime \prime W}\right), 8 / A p r i l / 2011$, four females (CL 6.0-7.6 mm), benthic sledge, 305316 m (EMU-9455). St. 19 (2837'37”N $112^{\circ} 41$ '05"W), 9/April/2011, one female (CL $6.0 \mathrm{~mm}$ ), 560-580 m, benthic sledge (EMU9456A). St. 20 (2846'29”N - 112\%45'40”W), 9/April/2011, 20 females (CL 6.0-9.3 mm), benthic sledge, 410-414 m (EMU-9457). St. $21\left(29^{\circ} 00^{\prime} 53^{\prime \prime} \mathrm{N}-112^{\circ} 51^{\prime} 31^{\prime \prime} \mathrm{W}\right)$, one female (CL $6.4 \mathrm{~mm}$ ), 9/April/2011, benthic sledge, 412-415 m (EMU-9456B).

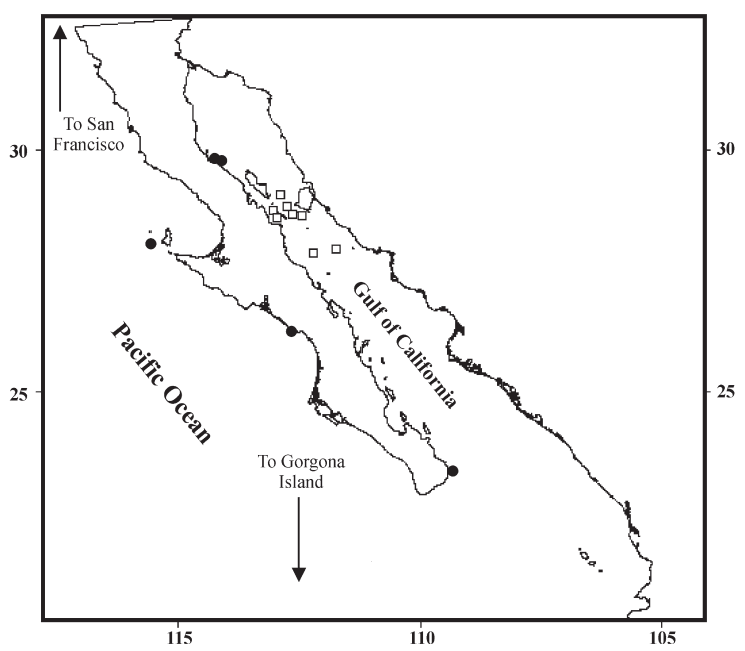

Figure 2. General distribution pattern of Neocrangon resima (Rathbun, 1902) along the coast of western America. Each dot off the coast of Mexico represent one sample. Squares $\square$, material of the TALUD XIV. Circles $\bullet$, other records.
Distribution: The type locality of Crangon resima is off San Diego, California ("Albatross" St. 2935; 32044'30”N - 117\%23'0”W), in 124 fm depth $(227 \mathrm{~m})$; depth range, from 44 to $266 \mathrm{fm}$ (81-487 m) (Rathbun, 1902). The type locality of Crago zacae is east of Cedros Island, west coast of Baja California, Mexico $\left(28^{\circ} 13^{\prime} \mathrm{N}-115^{\circ} 07^{\prime} \mathrm{W}\right)$, in $44 \mathrm{fm}$ depth (81 $\mathrm{m})$; additional material from Gorda Bank, east coast of Baja California Sur (Chace, 1937). The Scripps Institution of Oceanography catalogue reports one sample of $N$. zacae NW of Angel de la Guarda Island (29\%43'54”N - 11356'W) at $566-644 \mathrm{~m}$ depth (identified by M.K. Wicksten) (SIO, 1992). The general range of this species is from Monterey Bay, California, USA, to north of Gorgona Island, Colombia (Wicksten, 2011). Additional localities for Mexico reported in literature are San Domingo Point, west coast of Baja California (as N. zacae; Rathbun, 1902), and Conzag Bay, east coast of Baja California (Wicksten and Hendrickx, 2003) (Fig. 2). Word and Charwat (1976) provide a depth range of 73-183 $\mathrm{m}$ for $N$. zacae and of 60-227 for $N$. resima. The record of $N$. resima by Green and Butler (1988) for British Columbia is a misidentification and actually corresponds to $N$. communis.

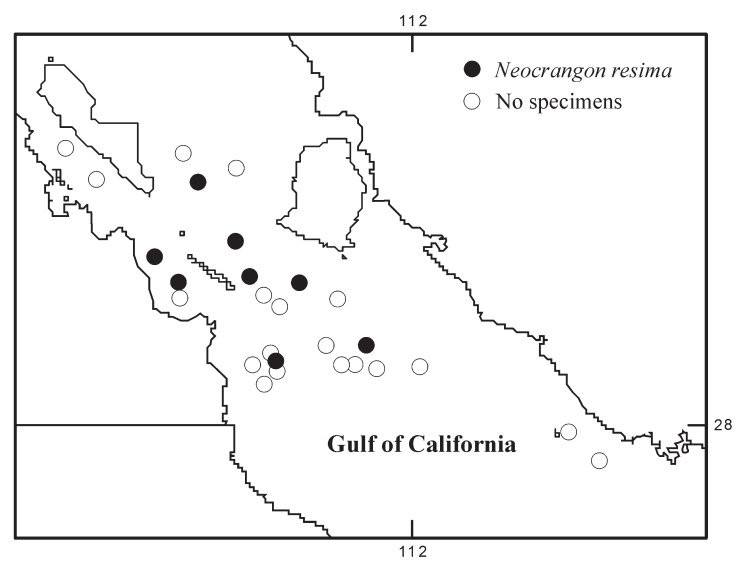

Figure 3. Localities where Neocrangon resima (Rathbun, 1902) was collected during the TALUD XIV cruise in the Gulf of California, Mexico.

Ecology: As noted previously, the general depth range of $N$. resima is from 60 to $644 \mathrm{~m}$. The material collected during the TALUD XIV cruise was caught between 205 and $580 \mathrm{~m}$. Epibenthic temperature and dissolved oxygen 
concentration varied from 6.21 to $11.29{ }^{\circ} \mathrm{C}$ and 0.50 to $1.54 \mathrm{ml} \mathrm{O}_{2} / 1$, with most records (4 out of 6 ) in concentrations $>1.0 \mathrm{ml} \mathrm{O}_{2} / 1$.

Remarks: The specimens examined belong to the genus Neocrangon as described by Zarenkov (1965). The characters provided by Wicksten (1996) to separate $N$. resima from the other species occurring in the region and her redescription of this species were used to identify the material examined. All specimens fit well with the description. Rostrum shape as well as position, size and number of teeth on carapace (Fig. 1) match illustrations provided by Schmitt (1921) and by Chace (1937, for N. zacae); they also lack a dorsal carina on the sixth abdominal somite, and the orientation of the dactyl with respect to the hand of the first cheliped is oblique (see Fig. 1). The plate (or carina) below the rostrum is relatively moderate in the specimens examined. According to Wicksten (1996), this character is variable in both $N$. resima and $N$. communis (Rathbun, 1899).

The 33 specimens examined represent the largest sample available to date for this species in the Gulf of California. However, no ovigerous female were observed. Considering the size of the sampling gear ( $2.35 \mathrm{~m}$ wide), the speed and duration of each haul (30 minutes), the density of $N$. resima is estimated between 2.7 and $54.0 \mathrm{org} / \mathrm{ha}$. The material collected during this survey confirms the presence of a widely distributed and relatively large population of $N$. resima in deep-water in the northern Gulf of California. However, additional sampling in this area is needed to establish the exact boundaries of its distribution, its abundance and reproductive strategy.

\section{Acknowledgements}

The author thanks all colleagues, students and crew members for their help in sampling activities aboard the R/V "El Puma" during the TALUD XIV cruise, and Mercedes Cordero for preparing the figures and the final edition of this manuscript.

\section{References}

Austin, W.C. 1985. An annotated checklist of marine invertebrates in the cold temperate northeast Pacific. Khoyatan Marine Laboratory, British Columbia. Vol. 3: 445682.

Chace, Jr. F.A. 1937. The Templeton Crocker Expedition. VII. Caridean decapod Crustacea from the Gulf of California and the west coast of lower California. Zoologica, 22 (8): 109-138.

Chace, Jr. F.A. 1984. The caridean shrimps (Crustacea: Decapoda) of the "Albatross" Philippine Expedition, 1907-1910, Part 2: Families Glyphocrangonidae and Crangonidae. Smithsonian Contributions to Zoology, 397: 1-63.

De Grave, S. and Fransen, C.H.J.M. 2011. Carideorum catalogus: the recent species of the dendrobranchiate, stenopodidean, procarididean and caridean shrimps. Zoologische Medededelingen, 89(5): $195-$ 589.

Goodwin, D.G. 1952: Some decapod Crustacea dredged of the coast of central California. Proceedings of the California Academy of Sciences, 27: 393-397.

Green, G. and T.H. Butler. 1988. Range extensions of three caridean shrimps to British Columbia waters. British Columbia Provincial Museum Contributions in Natural Sciences, 8: 1-7.

Hendrickx, M.E. 1993. Crustáceos decápodos del Pacífico Mexicano. p. 271-318. In: Salazar-Vallejo, S.I. and González, N.E. (eds), Biodiversidad Marina y Costera de México. Comisión Nacional de Biodiversidad y CIQRO, Mexico.

Hendrickx, M.E. 1995. CAMARONES. p. 417-537. In: W. Fischer, F. Krupp, W. Schneider, C. Sommer, K.E. Carpenter and V.H. Niem (eds), Guía FAO para la identificación de especies para los fines de la pesca. Pacífico centro-oriental. Vol. I. Plantas e Invertebrados. FAO, Roma, Italia. Hendrickx, M.E. 1996. New records of deep-water decapod crustaceans in the 
southeastern Gulf of California, Mexico. Revista de Biología Tropical, 44 (2B): 945947.

Hendrickx, M.E. 2005. Cap. 14. Crustacea 6. Decapoda: Dendrobranchiata, Caridea, Palinura, Anomura and Brachyura. p. 159-194. In: A distributional checklist of the macrofauna of the Gulf of California, Mexico. Part I. Invertebrates. [Listado y Distribución de la Macrofauna del Golfo de California, México, Parte I. Invertebrados]. Hendrickx, M.E., Brusca, R.C. and Findley, L.T. (eds), Arizona-Sonora Desert Museum. Hendrickx, M.E.2012.Los Glyphocrangonidae y Crangonidae (Crustacea: Decapoda: Caridea) recolectados durante los cruceros TALUD en el Pacífico mexicano. In: El proyecto TALUD. Instituto Nacional de Ecología, Secretaría del Medio Ambiente y Recursos Naturales (SEMARNAT). México. (in press).

Hendrickx, M.E. and Serrano, D. 2010. Impacto de la zona de mínimo de oxígeno sobre los corredores pesqueros en el Pacífico mexicano. Interciencia, 35(1): 12-18.

Holthuis, L.B. 1980. FAO species catalogue. 13. Marine lobsters of the world. An annotated and illustrated catalogue of species of interest to fisheries known to date. FAO Fisheries Synopsis, 125: 1-292.

Holthuis, L.B. 1993. The recent genera of the caridean and stenopodidean shrimps (Crustacea, Decapoda) with and appendix on the order Amphionidacea. National Natuurhistorisch Museum, Leiden. 328 p.

Komai, T. 2004. A new genus and new species of Crangonidae (Crustacea, Decapoda, Caridea) from the southwestern Pacific. Zoosystema, 26(1): 73-85.

Kozloff, E.N. 1974. Key to the marine invertebrates of Pudget Sound, the San Juan Archipielago, and adjacent regions. University of Washington Press, Seattle. 226 pp.

Kuris, A.M. and Carlton, J.T. 1977. Description of a new species, Crangon handi, and new genus, Lissocrangon, of crangonid shrimps (Crustacea: Caridea) from the California coast, with notes on adaptation in body shape and coloration. Biological Bulletin, 153: 540-559.

Luke, S. 1977. Catalogue of the Benthic Invertebrate Collections. I - Decapod Crustacea and Stomatopoda. SIO References Series, 77-9: 1-72.

Rathbun, M.J. 1902. Descriptions of new decapod crustaceans from the west coast of North America. Proceedings of the United States National Museum, 24(1272): 885905.

Rathbun, M.J. 1904. Decapod crustaceans of the northwest coast of North America. Harriman Alaska Expedition Washington, 10: 1-190.

Schmitt, W.L. 1921. The marine decapod Crustacea of California with special reference to the decapod Crustacea collected by the United States Bureau of Fisheries Steamer "Albatross" in connection with the biological survey of San Francisco Bay during the years 1913-1913. University of California Publications in Zoology, 23: $1-359$.

Serrano, D. and Hendrickx, M.E. 2011. Debajo de la zona de mínimo oxígeno. Investigación y Ciencia, 417: 13-15.

SIO. 1992. The marine shrimp of the Scripps Institution of Oceanography Benthic Invertebrate collection catalogue. Mimeographed report. 106 pp.

Wicksten, M.K. 1980. Range extensions of four species of crangonid shrimps in the eastern Pacific Ocean. Bulletin of the Southern California Academy of Sciences, 79: 38-41.

Wicksten, M.K. 1989. Ranges of offshore decapod crustaceans in the eastern Pacific Ocean. Transactions of the San Diego Society of Natural History, 21(19): 291-316.

Wicksten, M.K. 1996 Neocrangon zacae (Chace, 1937) synonymized with $N$. resima (Rathbun, 1902), and compared with $N$. communis (Rathbun, 1899) (Decapoda: Caridea: Crangonidae). Proceedings of the Biological Society of Washington, 109: 39-43.

Wicksten, M.K. 2011. Decapod crustaceans of the Californian and Oregonian zoogeographic provinces. Scripps 
Institution Library. Scripps Institution of Oceanography, UCSan Diego. eScholarship, University of California. 419pp. Electronic publication accessed at (http://escholarship. org/uc/item/7sk9t2dz?query=wicksten)

Wicksten, M.K. and M.E. Hendrickx. 2003. An updated checklist of benthic marine and brackish water shrimps (Decapoda: Penaoidea, Stenopodidea, Caridea) from the Eastern Tropical Pacific. p. 49-76 In: M.E. Hendrickx (ed), Contributions to the Study of East Pacific Crustaceans 2. [Contribuciones al Estudio de los Crustáceos del Pacífico Este 2] Instituto de Ciencias del Mar y Limnología, UNAM. Mexico.

Word, J.Q. and Charwat, D.K. 1976. Invertebrates of southern California coastal waters. II. Natantia. Southern California Coastal Water Research Project. 238 p.

Zarenkov, N.A. 1965. Reviziya rodov Crangon Fabricius i Sclerocrangon G.O. Sars (Decapoda, Crustacea) [Revision of genera Crangon Fabricius and Sclerocrangon G.O. Sars (Decapoda, Crustacea)]. Zoological Zhurnal, 44(12): 1761-1775. 